\title{
Hybrid assays: the next big thing?
}

\author{
Brian P Booth*,1 \& Brian Furmanski ${ }^{1}$ \\ ${ }^{1}$ US FDA, CDER, Office of Translational Sciences, Office of Clinical Pharmacology, Silver Spring, MD, USA \\ *Author for correspondence: Brian.booth@fda.hhs.gov
}

First draft submitted: 9 May 2018; Accepted for publication: 11 May 2018; Published online: 11 July 2018

Keywords: acceptance criteria • digestion • mass spectrometry platforms • peptide selection • stability

In the near-term, the wide-spread use of hybrid assays appears to be 'the next big thing' in bioanalysis as evidenced by its inclusion in recent professional publications (Table 1) and discussions at scientific meetings. Consequently, the US FDA has been prompted to issue guidance/specifications/expectations for hybrid assays; however, regulatory experience with these modalities has been extremely scarce to date. Much of the interest in FDA guidance has been for acceptance criteria around accuracy and precision for hybrid assays. Several authors have privately and publicly promulgated the use of the ligand-binding assay (LBA) criteria $(20 / 25 \%)$ because of the use of LBA to enrich the samples [1]. The FDA has not stated a position on this issue yet [2], due to the lack of data in regulatory submissions, but it has indicated that those criteria would be based on the data generated over time. However, review of the recent literature (Table 1) tends to indicate overwhelmingly that chromatographic acceptance criteria are easily met. So, with data like these, chromatographic acceptance criteria would seem to be the more reasonable choice.

The typical validation parameters in and of themselves are not the issues of greatest interest. This combinatorial approach of a hybrid assay, and the inclusion of a digestion step is much more complex than the average assay for either a small-molecule drug, measured by LC-MS or therapeutic protein assayed by LBA. Consequently, the FDA has questions about these 'new' steps in the process and how they affect reliability of the assay.

- What peptide should be selected to monitor? Injecting the intact protein onto the LC/MS is currently not feasible, and most groups are making decisions about digesting the protein and isolating a particular peptide that represents the intact molecule. In nonclinical studies, a 'universal' peptide, which is a segment of the protein that is conserved across animal species, has been used to generate assays and data. But once the studies in humans begin, a new assay based on a signature peptide is needed (because humans do not share these conserved stretches of antibody). How do the nonclinical data compare with the human assays (do they need to)? Is there a bias that has to be accounted for in order to extrapolate nonclinical findings to humans to assess safety evaluations?

- How reliable is the selection of the signature peptide in human studies? These are often the segments of the heavy chain of an antibody. Do these reliably indicate the identity of the intact analyte of interest? Or could they be confounded by fragments of the antibody in the circulation or other plasma contaminants? Should we be monitoring two fragments: heavy chain and light chain? would that be sufficient? Some sample preparations might exclude these fragments, in which case, they would not be measured. But should they be monitored? Would a qualitative assessment of the remaining peptides within a digest also be appropriate? If so what percentage of the therapeutic protein should be monitored qualitatively (e.g., 10, 50 or 80\%). Furthermore, there are some anecdotal reports that monoclonal antibodies (mAbs) may undergo biotransformations (e.g., oxidation) that may impact biological activity (are we on the verge of exploring/understanding mAb metabolism?); can these fragments be assessed reliably?

- What instrumentation will be utilized in assay validation and during study runs? A number of platforms (e.g., Triple Quads, Ion traps, Q-TOFs and Orbi Traps) are available for the quantitation of therapeutic proteins. Early in assay development high-resolution instruments are typically used as they provide the user with more information (spectral counting) and selectivity through higher mass resolution. Conversely, later in assay validation and during study runs, unit resolutions instruments are used as they cost less than highresolution instruments and are more user friendly. Is switching between platforms an acceptable practice? If so how do we translate data generated across multiple platforms? Should high-resolution instruments be used 


\begin{tabular}{|c|c|c|c|c|c|c|}
\hline Study (year) & Analyte & Bias \% LLOQ (bold) & $\begin{array}{l}\text { Precision \% LLOQ } \\
\text { (bold) }\end{array}$ & Internal standard & $\begin{array}{l}\text { FDA BMV guidance } \\
\text { LC/MS criteria }\end{array}$ & Ref. \\
\hline \multirow[t]{2}{*}{ Willrich M et al. (2015) } & $\begin{array}{l}\text { Infliximab heavy chain; human } \\
\text { serum; } 1-100 \mu \mathrm{g} / \mathrm{ml}\end{array}$ & NA & 7 to 15 & $\begin{array}{l}\text { Horse IgG peptide and } \\
\text { stable isotope-labeled (SIL) } \\
\text { peptide }\end{array}$ & Yes & [3] \\
\hline & $\begin{array}{l}\text { Infliximab light chain; human } \\
\text { serum; } 1-100 \mu \mathrm{g} / \mathrm{ml}\end{array}$ & NA & 5 to 13 & & Yes & \\
\hline \multirow[t]{2}{*}{ Becher F et al. (2017) } & $\begin{array}{l}\text { Cetuximab (HT4) heavy chain; } \\
\text { human serum; } 1-1000 \mu \mathrm{g} / \mathrm{ml}\end{array}$ & -6.7 to 3 & 9.5 to 14.7 & $\begin{array}{l}\text { Proteotypic peptides } \\
\text { (SIL)peptides }\end{array}$ & Yes & [4] \\
\hline & $\begin{array}{l}\text { Cetuximab (LT3) heavy chain; } \\
\text { human serum; } 1-1000 \mu \mathrm{g} / \mathrm{ml}\end{array}$ & -11.6 to 7 & 5.9 to $14.3 ; 6.4$ & & Yes & \\
\hline \multirow[t]{4}{*}{ Li H et al. (2013) } & $\mathrm{mAC}$; rat plasma; $0.1-15.0 \mu \mathrm{g} / \mathrm{ml}$ & -5.6 to $7.4 ; 6.5$ & 7.9 to $11.2 ; 8.1$ & $\begin{array}{l}\text { SIL- } \alpha \mathrm{DA} \text { that are situated } \\
\text { at the similar CDR location }\end{array}$ & Yes & [5] \\
\hline & $\alpha \mathrm{DA}$; rat plasma; $0.1-15.0 \mu \mathrm{g} / \mathrm{ml}$ & -8.2 to $5.8 ; 4.9$ & 2.4 to $6.6 ; 4.1$ & & Yes & \\
\hline & $\alpha \mathrm{DB}$; rat plasma; $0.1-15.0 \mu \mathrm{g} / \mathrm{ml}$ & -7.8 to 0.9 & 5.3 to 9.6 & & Yes & \\
\hline & $\alpha \mathrm{K}$; rat plasma; $0.1-15.0 \mathrm{\mu g} / \mathrm{ml}$ & 1.5 to $5.9 ; 2.8$ & 6.7 to 17.7 & & Yes for accuracy & \\
\hline Heudi O et al. (2008) & $\begin{array}{l}\text { mAb;marmoset } \\
\text { serum; } 5-750 \mathrm{ug} / \mathrm{ml}\end{array}$ & 2.6 to 8.3 & 6 to 15.9 & $\begin{array}{l}\text { Synthetic signature } \\
\text { peptide }\end{array}$ & Yes for accuracy & [6] \\
\hline \multirow[t]{2}{*}{ Xu K et al. (2014) } & $\begin{array}{l}\text { mAb-A; human } \\
\text { serum; } 0.1-20 \mathrm{ug} / \mathrm{ml}\end{array}$ & 7.66 to 10.5 & 2.85 to 7.18 & $6.56 / 5.85$ & Yes & [7] \\
\hline & $\begin{array}{l}\text { mAb-B; human } \\
\text { serum; } 0.1-20 \mathrm{ug} / \mathrm{ml}\end{array}$ & -4.18 to 11.5 & 3.67 to 11.9 & 10.6/10.1 & Yes & \\
\hline \multirow[t]{2}{*}{ Ewles M et al. (2016) } & $\begin{array}{l}\text { Trastuzumab QCs; human } \\
\text { serum; } 0.25-250 \mathrm{ug} / \mathrm{ml}\end{array}$ & -4.9 to 0.3 & 1.4 to 5.1 & $0.7 / 3.0$ & Yes & [8] \\
\hline & $\begin{array}{l}\text { Bevacizumab QCs; human } \\
\text { plasma; } 0.1-100 \mathrm{ug} / \mathrm{ml}\end{array}$ & -7.3 to 4.5 & 4.7 to 13.6 & $3.9 / 3.1$ & Yes & \\
\hline \multirow[t]{2}{*}{$\begin{array}{l}\text { Mekhssian K et al. } \\
\text { (2014) }\end{array}$} & $\begin{array}{l}\text { Rituximab QCs; human } \\
\text { serum 1-150 ug/ml HC }\end{array}$ & -4.5 to 0.8 & 3.3 to 10.1 & na & Yes & [9] \\
\hline & $\begin{array}{l}\text { Rituximab QCs; human } \\
\text { serum 1-150 ug/ml LC }\end{array}$ & -1.9 to 0.4 & 4.6 to 12.8 & na & Yes & \\
\hline $\begin{array}{l}\text { Furlong MT et al. } \\
\text { (2014) }\end{array}$ & $\begin{array}{l}\text { IgG mAb; human } \\
\text { serum 5-400 ug } / \mathrm{ml}\end{array}$ & -7.8 to 7.2 & 3.2 to 7.3 & na & Yes & [10] \\
\hline Kaur S et al. (2016) & $\begin{array}{l}\text { mAb; monkey serum;1 } \\
0.1-19 \mathrm{ug} / \mathrm{ml}\end{array}$ & 1.96 to 10.9 & 5.14 to 8.84 & na & Yes & [11] \\
\hline Peng K et al. (2014) & RG7652; human serum 0.1 ug $/ \mathrm{ml}$ & not reported & 4 to 9 & na & Yes for precision & [12] \\
\hline
\end{tabular}

throughout a therapeutic protein's life cycle as they provide more information that can be assessed retrospectively (e.g., biotransformations)?

- How will sample stability be assessed? Long-term stability is often conducted with the peptide, but does that reflect what we need to know? Does the intact protein behave the same way? How do you handle changes in peptide solubility? And which species should be monitored on the benchtop? The peptide? The intact molecule? Both because we are handling both?

- Furthermore, what about protein digestion? Since the digestion generates the reference standards, is the digestion step complete (or at least linear) across the range of protein concentrations needed? The outcomes would have a profound impact on the accuracy of the assay. So would the selection of the internal standard. Options include stable labelled mAb (SILmAb), SIL labeled peptides and 'winged' peptides. Each of these offers different advantages; each is added at different points in sample processing, and consequently, may not account for all potential issues that might arise during sample preparation.

Other questions that arise include what mass fragments should be monitored. Peptide mass spectra often generate multiple peaks: which ones should be monitored - some representative peaks, or do we need all of them?

These are some of the questions we have to grapple with regarding hybrid assays; and undoubtedly others will crop up later. Traditionally, there is always fear about being 'the first guy' to try out something new in the regulated space. But a lot of work has been done in this field, and the agency has traditionally worked with drug development scientists to employ new technologies and approaches. Hybrid assays are no different in that respect. The best advice that can be offered is to seek regulatory input on the use of hybrid assays early during development (ideally before 
first in human studies). The FDA meets with industry representatives around many issues in drug development and this is a good pathway to resolve many of the questions about hybrid assays. The questions posed in this article are good starting point for discussions with the agency. We look forward to the implementation of hybrid assays in future applications.

\section{Disclaimer}

The views expressed are those of the authors and do not reflect official policy of the FDA. No official endorsement by the FDA is intended or should be inferred.

\section{Financial \& competing interests disclosure}

The authors have no relevant affiliations or financial involvement with any organization or entity with a financial interest in or financial conflict with the subject matter or materials discussed in the manuscript. This includes employment, consultancies, honoraria, stock ownership or options, expert testimony, grants or patents received or pending, or royalties.

No writing assistance was utilized in the production of this manuscript.

\section{References}

1. Jenkins R, Duggan JX, Aubry AF et al. Recommendations for validation of LC/MS/MS bioanalytical methods for protein biotherapeutics. AAPS J. 17, 1-16 (2015).

2. US FDA. Guidance for Industry: Bioanalytical Method Validation (2018). https://www.fda.foc/downloads/Drugs/GuidanceComplianceRegulatoryInformation/Guidances/UCM07107.pdf

3. Willrich MA, Murray DL, Barnidge DR et al. Quantitation of infliximab using clonotypic peptides and selective reaction monitoring by LC/MS/MS.Int. Immunopharmacol. 28, 513-520 (2105).

4. Becher F, Ciccolini J, Imbs DC et al. A simple and rapid LC/MS/MS method for therapeutic drug monitoring of cetuximab: a GPCO-UNICANCER proof of concept study in head and neck cancer patients. Sci. Rep. 7, 1-11 (2017).

5. Li H, Ortiz R, Tran LB et al. Simultaneous analysis of multiple monoclonal antibody biotherapeutics by LC-MS/MS method in rat plasma following cassette-dosing. AAPS J. 15, 337-346 (2013).

6. Heudi O, Barteau S, Zimmer D et al. Towards absolute quantification of therapeutic monoclonal antibody in serum by LC-MS/MS using isotope-labelled antibody standard and protein cleavage isotope dilution mass spectroscopy. Anal. Chem. 80, 4200-7 (2008).

7. Xu K, Liu L, Maia M et al. A multiplexed Hybrid LC-MS/MS pharmacokinetic assay to measure two co-administered monoclonal antibodies in a clinical study. Bioanalysis 6(13), 1781-1794 (2014).

8. Ewles M, Mannu R, Fox C et al. LC-MS/MS startegies for therapeutic antibodies and investigation into the quantitative impact of anti-drug antibodies. Bioanalysis 8(24), 2565-2579 (2016).

9. Mekhssian K, Mess JN, Garofolo F. Application of high-resolution MS in the quantification of a therapeutic monocloncal antibody in human plasma. Bioanalysis 6(13), 1767-1779 (2014).

10. Furlong MT, Titsch C, Xu W et al. An exploratory universal LC-MS/MS assay for bioanalysis of hinge region -sTabilized human IgG4 mAbs in clinical studies. Bioanalysis 6(913), 1747-1758 (2014).

11. Kaur S, Liu L, Cortes DF et al. Validation of a biotherapeutic immunoaffinity-LC-MS/MS assay in monkey serum: 'plug-and-play' across seven molecules. Bioanalysis 8(15), 1565-1577 (2016).

12. Peng K, Xu K, Liu L et al. Critical role of bioanalytical strategies in investigation of clinical PK observations, a Phase I case study. MAbs 6(6), 1500-1508 (2014). 
